\title{
支部委員会報告
}

「第 1 回 次世代の臨床外科医のための特別セミナー」の報告

日本臨床外科学会の支部活動の活性化と若手外科医の啓発を目的として, 本年 2 月 2 日・ 3 日の 2 日 間にわたり東京・品川において，第 1 回「次世代の臨床外科医のための特別セミナー」が行われた．全 国34支部から, 各 2 名ずつの40歳以下の中堅・若手医師および各支部長が参加し, 総計126名の出席者 であった，日本の外科をリードする教授・病院長が揃った講師陣による熱のこもった講演と，報道関係 者による「メディアから外科医に期待すること」のパネルディスカッションが行われた. 今回のセミナ 一は参加者全員が泊り込みであり, 初日夜の夕食懇親会にて大いに盛り上がった。北海道から沖縄まで の外科医が，臨床現場で遭遇している問題を語りあうことで親睦を深めることができた．とくに日ごろ 多忙な日常診療に追われる若手医師は, 相互に大いなる刺激を受けて明日への活力となったようである.

以下に特別セミナーの各講演の要旨をまとめたので報告する.これらの講演は学会HPにおいてスト リーミングシステムで閲覧可能の予定である. なお2014年 2 月 1 日・ 2 日に第 2 回が開催される.

期 日 2013年 2 月 2 日（土）午後 3 時より 2 月 3 日（日）午後 3 時まで

参加者 全国各支部から若手 (40歳未満) 外科医 2 名ずつを各支部から推薦並びに支部長 会 場グランドプリンスホテル新高輪

セミナープログラム

2 月 2 日（土）

開会挨拶跡見裕 会長

講演

1. IT 化時代の外科診療 竹之下誠一（福島医大） 司会 小西 敏郎

2. 外科診療とDPC 小山 信彌（東邦大学大森） 司会 木村 泰三 パネルディスカッション「メディアから外科医に期待すること」

司会 炭山 嘉伸, 井田 由美（日本テレビキャスター）

パネラー 浅井 文和 朝日新聞編集委員

木村 良一 産経新聞論説委員

高田 和男 日本テレビ解説委員

岩本裕 NHK放送文化研究所・世論調査部副部長

保高 芳昭 読売新聞論説委員

2 月 3 日（日）

特別講演私の理想とする臨床外科医

3. 私の理想とする臨床外科医 - 心臓血管外科 順天堂大学

4. 私の理想とする臨床外科医 - 食道外科 恵佑会札幌

5. 私の理想とする臨床外科医 - 肝臟外科
日赤医療センター
天野 篤 (矢永 勝彦)

細川 正夫 (万代 恭嗣)

幕内 雅敏 (横森 欣司) 
講演

6. 女性外科医のワークライフバランス 平松 昌子（大阪医科大学）

7. 海外留学のすすめ

森正樹（大阪大学）

司会 中井 美穂（キャスター）

司会 望月 英隆

閉会のことば炭山 嘉伸 副会長・支部委員会委員長

\section{IT 化時代の外科診療}

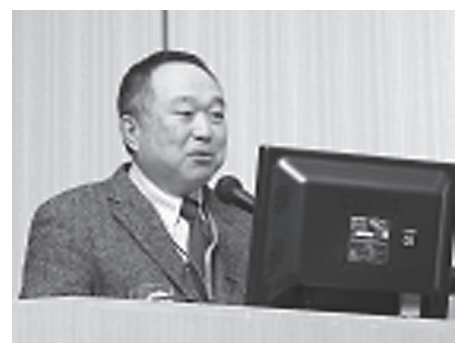

演者 : 竹之下誠一 先生

(福島県立医科大学器官制御外科)

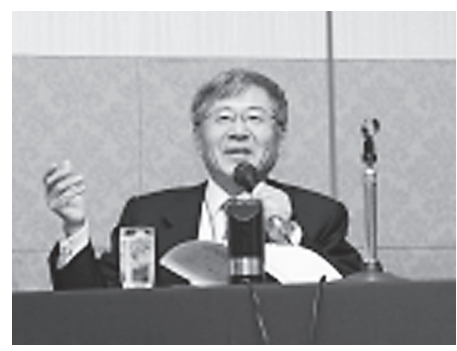

司会：小西 敏郎 先生 (NTT東日本関東病院)

震災からの福島医大復興ビジョンのビデオを供覧. その中で, 福島国際医療科学センターを紹介し, 先端臨床研究センターでの遠隔医療を紹介された。また, 福島県での光ファイバー網を利用した診療情 報共有をめざす福島県医療福祉情報ネットワーク構想, 福島県での産学一体化したトランスレーショナ ルリサーチとしてのプロジェクト「遺伝子発現解析技術を活用した個別がん医療の実現と抗がん剂開発 の加速」, 海外とのICT ネットワークにより可能となった最新の MRI/PETなどを詳細に紹介された.

\section{2. 外科診療と DPC}

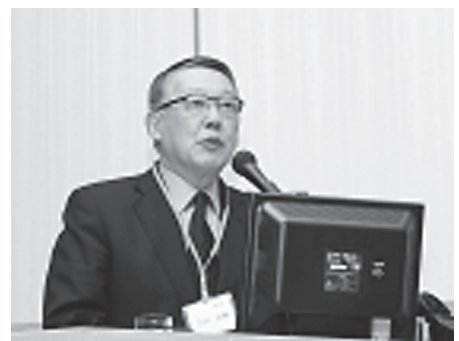

演者：小山 信彌 先生

(東邦大学医療センター大森病院心臓血管外科)

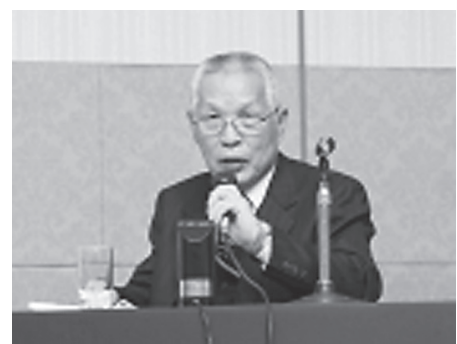

司会 : 木村 泰三 先生

(富士宮市立病院名誉院長)

平成24年度診療報酬改定の内容をまず紹介された。次いで平成22年にDPCから改称されたDPC/ PDPSを解説された. 特に, 病院ごとに設定されていた調整係数から, 病院群ごとに設定される基礎係数・ 機能評価係数IIへの改定, 機能で分類された DPC 病院I群・II群・III群の違いと特徽などを詳細に解説 された. DPC/PDPSに合わせて診療をおこなうのではなく, 患者にとって必要な検査, 治療を行って いくことがDPC/PDPSを正しい方向へ改訂していくために重要であることを強調された. 


\section{パネルディスカッション「メディアから外科医に期待すること」}

司会：炭山 嘉伸 先生 (東邦大学), 井田 由美氏 (日本テレビキャスター)

パネリスト 浅井 文和 朝日新聞編集委員

木村 良一 産経新聞論説委員

高田 和男 日本テレビ解説委員

岩本裕 NHK放送文化研究所・世論調査部副部長

保高 芳昭 読売新聞論説委員

5 人のパネリストがまず自己紹介を行った。次いで, 医師数や医療の地域間格差・診療科間格差につ いてディスカッションが行われた．外科医や外科志望者の減少には新臨床研修制度がきっかけになった が，外科は労働環境が厳しいことが多く，診療科間格差解消は容易ではなく，医師の診療科選択に制限 を設けるなど計画的配置の必要性などが議論された.

外科医離れを防ぐためには学生や研修医などの若い世代に先輩外科医が外科の魅力を示さなければな らないことなどが述べられた，フロアーの若手医師から地域間格差に関して，地方でも臨床・教育シス テムがしっかりしていれば, 全国から優秀な学生を高倍率のマッチングとなるくらい集められること, また 2 名の若手外科医からは内科志望で臨床研修をスタートしたが，研修中に外科に魅力を感じて外科 に変更してよかったと思っているとの先輩外科医にとって元気の出る発言も認められた.「理想の外科 医像として, 新しいものに挑戦するとともに, 患者の立場に立って, 人の痛みの分かる外科医であって ほしい」との意見が， 5 人のパネリスト共通の意見であった.

\section{3． 私の理想とする臨床外科医一心臓血管外科}

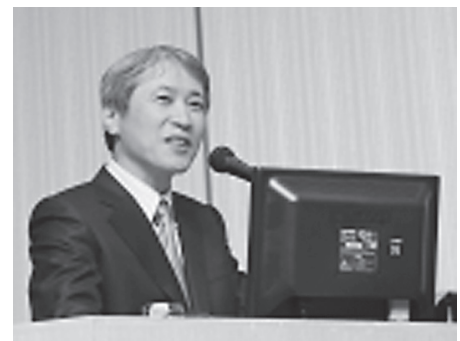

演者: 天野 篤 先生

(順天堂大学心臟血管外科)

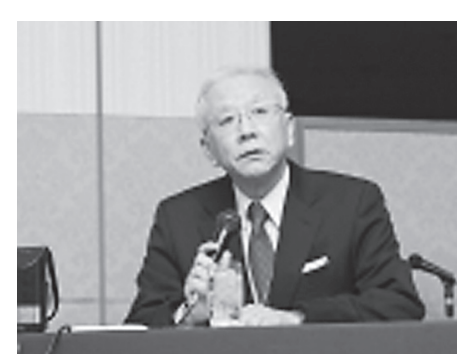

司会 : 矢永 勝彦 先生

(東京慈恵会医科大学外科)

まず御自身の略歴（1983日大卒，関東逓信病院で 2 年間研修，1985～亀田総合病院，1991 新東京病 院，1996には年間300例以上「松戸の奇跡」，2001～昭和大学横浜市北部病院，2002～順天堂大学）を紹 介された，過去の手術症例数が6,000例以上，昨年は505例.「一途一心」との銘を挙げられ，閃き，思 いついたこときちんと検証していくことの重要性を述べられた.オフポンプ手術をビデオを交えて解説 されるとともに，天皇陛下手術にまつわるエピソードなども紹介された，目標とする臨床外科医は「メ スよ輝け」の当麻鉄彦とのことであった。 


\section{4．私の理想とする臨床外科医一食道外科}

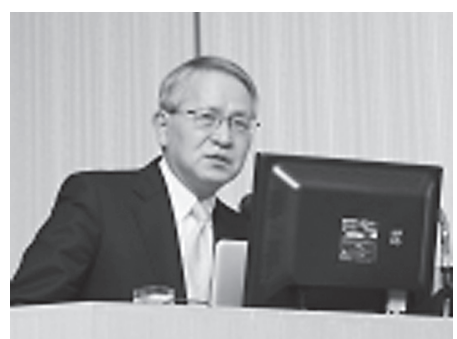

演者：細川 正夫 先生 (恵佑会札幌病院)

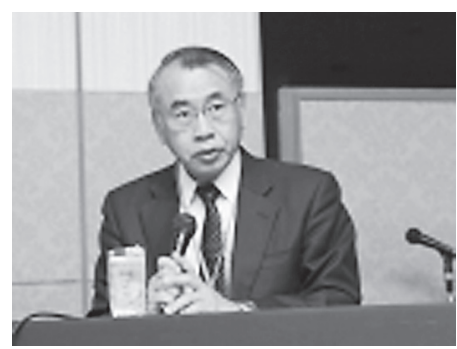

司会 : 万代 恭嗣 先生 （社会保険中央総合病院）

まず御自身の略歴（1968北大卒，1971〜国立がんセンター，1974〜北大 2 外，1981恵佑会札幌病院開 設，1994恵佑会東病院開設，2009地域がん診療連携拠点病院，2012第 2 病院開設（東病院閉鎖））を紹 介された. 2012年には御自分の施設で食道癌134例, 胃癌222例, 大腸癌294例の切除を行われたとのこ とであった，食道癌治療に関して, 癌の根治性 ( 3 領域郭清), 機能温存 (頝部食道癌喉頭温存), 安全 性 (Collard変法), 集学的治療 (CRT, サルベージ手術) について御自身の考元方と成績を紹介された. 今後望まれる臨床外科医像として，それぞれの環境でベストを尽くすとともに，自分の実力を客観的に 評価し, さらに患者の背景までよく理解して患者との信頼関倸を築くことのできる医師と述べられた。

\section{5．私の理想とする臨床外科医一肝臓外科}

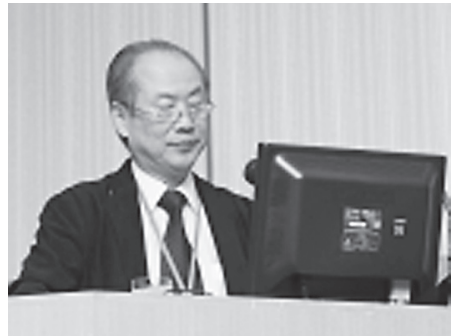

演者：幕内 雅敏 先生

(日赤医療センター)

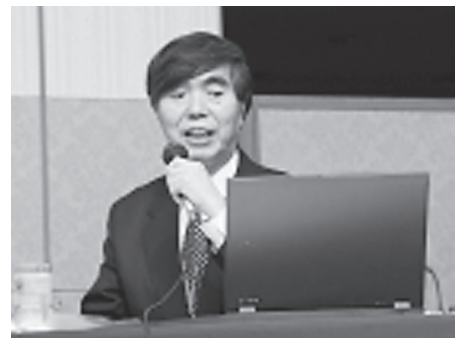

司会：横森 欣司 先生

（富士フィルム西麻布本社健康管理室）

英文論文計938編，Impact factor 計3,095点を司会の横森先生がまず紹介された。御自身は，理想の臨 床外科医の要点として, 心体技を鍛えること, 臨床と学問のバランス, 手術上手・新しい手術の考按を 挙げられた，肝蔵外科を志した理由も紹介．肝蔵外科における最近の進歩として, no mortality hepatectomy, 三次元シミュレーション, 系統的亜区域切除, 門脈枝塞栓術, 門脈腫瘍栓 HCC 治療（術前 $\mathrm{TACE}$ ), 生体肝移植, 転移性肝癌切除を解説された。最後に元通産審議官天谷直弘氏の「プロの心得」 を紹介された。 


\section{6. 女性外科医のワークライフバランス}

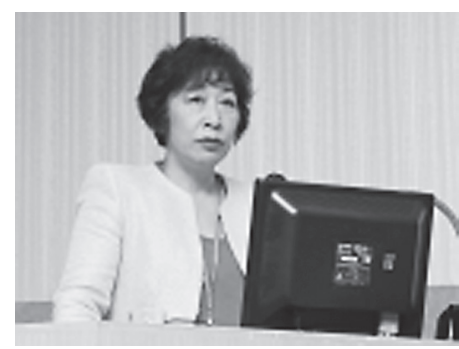

演者 : 平松 昌子 先生

(大阪医科大学一般 - 消化器外科)

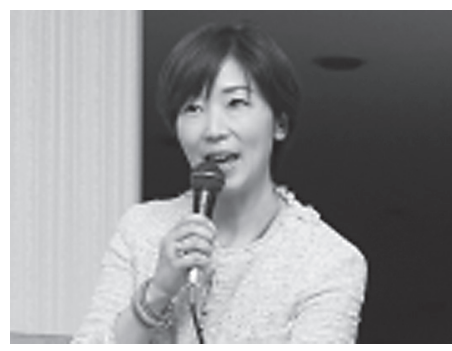

司会 : 中井 美穂 氏

(キャスター)

まず御自身の略歴（1984大阪医大卒，一般・消化器外科入局，関連病院等での臨床経験を経て，1994 からワシントン大学留学, 1998より食道疾患を担当, 同時に大阪医大での女性医師支援のために活動) とともに，これまでの本邦执よび米国での外科医の環境を紹介された，女性外科医が勤務を継続するた めには, 育児支援, 復職支援に加えて勤務形態の多様化（シフト制・チーム制など），キャリアアップ 支援が必要で, このような取り組みは外科医全体のワークライフバランスを改善すると述べられた.

\section{7．海外留学のすすめ}

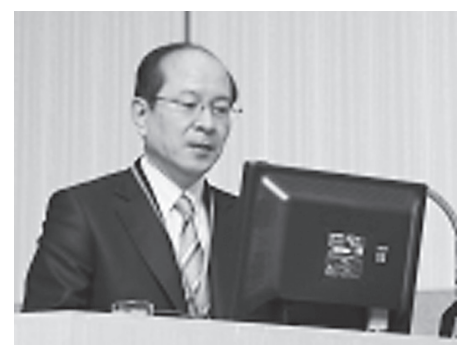

演者：森 正樹 先生 (大阪大学消化器外科)

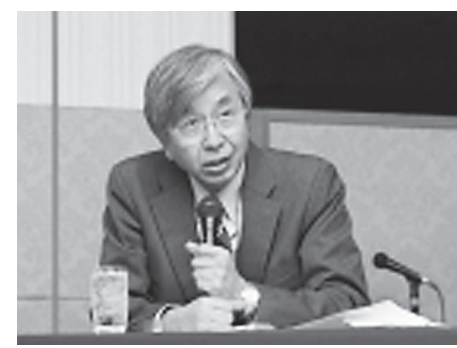

司会：望月 英隆 先生

(防衛医科大学校名誉教授)

最近の 3 人の留学生の留学の経緯や米国での生活の実際を紹介された. (1) 2001年阪大卒の秋田裕史先 生. 2010 2 年間 NIHに肝癌の発癌研究で留学. 明確な目標があれば留学は人生にプラス。(2)1996年 卒阪大心外吉川泰司先生. ECFMG を取得しエール大・ハーバード大に臨床で留学, 圧倒的に多い手術 経験症例数が動機. (3)1994年阪大卒 (学士入学) の丸橋繁先生. Baylor University Medical Centerに 肝移植臨床で留学. 迷ったら挑戦すべしとの言. 以上の 3 名の若手留学生の経験・意見を紹介されて, 最後に大阪大学の取り組みとして, がん幹細胞治療, 人に代わって実験を任せられるヒト型汎用ロボッ 卜も紹介された。 